\title{
Innovative Development and Practice of Central Chinese Traditional Folk Art in Art Design Education Reform in Creative Economy Era
}

\author{
Fei Gao \\ Henan Institute of Education, Zhengzhou, 450046, China
}

Keywords: Folk art culture in Central China, Design, Art Design education, Reform

\begin{abstract}
Very rich traditional folk art culture contains in Central China. Inheriting and carrying forward these folk art resources in the education form is human obligatory responsibility for development of society and national culture. Meanwhile, folk art inheritance will also bring infinite vitality to education and deepens the emotion of local people for local traditional culture. This paper aims to explore and analyze fusion of folk art culture and art design education in Henan. Through specific teaching practice, the thought of local folk art and college art education reform and new creative development direction of folk art design are explored.
\end{abstract}

\section{Necessity of folk art culture and design education reform in creative economy era}

Nowadays, cultural creative industry is flourishing in China and has become a new driving force to promote development of local economy. Meanwhile, as people have approved intangible cultural heritage in recent years, China's excellent traditional folk culture heritages are mostly designed and developed again. However, we can find in the market that many products fail to be fully innovated. It is thus hard to arouse resonance of modern people. Thus, cultural creative industry where traditional folk art spirit is rooted urgently needs new force. Creative talent training is the key. How should college art design education let traditional folk art enter campus? How to make traditional folk art create new approaches in modern design education platform and cultivate design talents which comply with market demand? These have become urgent topics in need of researches and solutions.

In 1990s, UNESCO proposed to pay attention to development the due national characteristics of traditional folk art education, inherit and publicize them to the world and let national culture become world culture in "international seminar for education in the $21^{\text {st }}$ education". Seeing from development trend of modern education, this is indeed a significant proposal which can influence development of world education. Meanwhile, it also influences reform and innovation of China's art design education. Fusion of traditional folk art and modern design becomes one of exploration emphases in the world. In 2002, "world heritage year" conference proposed to introduce folk culture art as human culture heritance in higher education. In recent years, education institutions and schools in various places have greatly promoted development and reform of folk art education so as to retain and inherit local traditional folk characteristics to the largest extent.

Henan is in Central China with long historic culture and contains multiple traditional art cultures such as Huaiyang Clay Dogs, Ruyang Ru Porcelain, Shenhou Jun Porcelain, Xinyang Wicker-works and Xingyang Wheat-works. They are deposited, inherited and continued in history. Their cukture nature, thought nature and innovation can provide rich nutrition for creation and development of modern art design. They are the genes of traditional culture and have far-reaching significance for national blood inheritance. Fusion of connotation form and value of folk art in Central China into local college art design teaching in Henan Province can contribute to improving teaching contents, creating teaching methods and forming characteristic specialty. Besides, college art design education can provide more professional platform for inheritance, innovation and development of folk art in Central China. Folk art inheritance is the "source" of modern art design teaching. They have mutual penetration, dependence, connection and influence relations. [1] Therefore, exploration of inheritance and innovative development of folk art in Central China in art design teaching can not just develop characteristic and culture of art design education in local colleges, but also provide intelligent support and talent guarantee for the survival and continuity of traditional folk art and further facilitate development of cultural creative industry in Henan. 


\section{Reflection of Central Chinese folk art in art design teaching}

\section{Improve teaching connotation and prefect teaching mode}

All types of folk art studios may be built according to specialty demands in college art design teaching, such as ceramics studio, weaving art studio, folk sculpture studio and studio for New Year pictures. Course teaching and training mode adopt the teaching mode which combines teachers' design idea, teaching thought and technical guidance of folk artists. "Studio system" may make students learn in practice and master culture connotation, manufacturing method and technological process of all kinds of traditional folk arts in Central China, and fuse with knowledge of professional courses. Theoretical and modern design methods may be designed according to the specialty. In design process, relevant traditional culture knowledge and expression modes of folk art should be combined to "experience differences and seek the common points" so as to improve design ability and level. In this way, the works not just innovate in the form, but also cultural connotation also promotes. The teaching mode of folk art studio not merely effectively fuses traditional art in design teaching, but also changes the one-sided practice of copying and directly quoting teaching modes of other regions or countries. Local design teaching mode is formed and perfected.

\section{Develop characteristic teaching and enrich teaching modes}

In college art design teaching, characteristic teaching is the development superiority. The idea and mode of local folk art is fused in design teaching in combination of regional characteristics, which offers a thought and approach for development of characteristic specialties of local colleges. The formation of characteristic specialties needs common construction of "human" and "materials". "Human" includes teaching resource, manpower, methods and achievements. "Materials" contain teaching equipment, teaching materials and data. In terms of teaching staff construction, it is required to actively encourage and support in-service teachers to engage in advanced studies and research the theories, manual skills and techniques in their spare time so as to form rational teaching team of "specialty leaders, teaching backbones and young teaching masters". During characteristic teaching material and database construction, regional folk art knowledge should be properly included according to specific requirements while basic theories are set forth. Digitization technology may be introduced in specialty teaching to gradually establish the database of local folk art culture resources and local folk art system. In addition, digitization technology brings convenience for teaching demonstration, data query and method application in teaching and practice. Furthermore, research results and teaching achievements in characteristic teaching can be transformed into productivity to drive development of local creative industry. In the aspect of personnel training, it is required to focus on digestion ability cultivation, seek the relationship between modern design and traditional folk art, and adopt question-based teaching method to encourage students to apply modern design mode to reduce and innovate on the basis of traditional culture. Generally speaking, art deign characteristic specialty construction in local colleges should closely focus on regional cultural resources and combine personnel cultivating program to construct characteristic practical teaching system and practical teaching base, actively carry out art practical teaching with regional characteristics and cultivate applied professional design talents who adapt the need of social and economic development.

\section{Exploit design thinking and boost professional skills}

Fusion of local folk art in art design teaching can exploit students' originality thought and boost their art creativity and practical ability. Folk art development is actually the development of art creativity. It feeds back to personae training in teaching practice. [2] Creative thinking training is the key to art creation ability cultivation. During teaching art design courses, absorbing and referring to creative ideas and methods of Central Chinese traditional folk art and making progress on the basis of folk art culture is an important approach to improve design education and develop local design. In this process, teaching contents are enriched, and students' view is expanded. Besides, this can motivate students' creativity, imagination, enlighten and guide students to conduct creative thinking. [3] Folk art education and teaching intensify students' practical design ability subtly. Since the form and commutation of local folk art are abundant, it is necessary to improve continually students' practical 
design and operation ability and skills through field investigation, thinking, analysis, practice, excavation and experiencing of cultural concepts and art design value in teaching practice. Practical teaching system can effectively enhance students' initiative and make them learn to study. Learning should be based in practice and enlighten students to accumulate knowledge through practical exploration, establish rational knowledge structure and apply all kinds of thinking modes and means to develop creative ability. The essence of practical activity of art design is creation with certain purpose by using corresponding art design means and materials. Such activity owns obvious purpose and practice. Students achieve social value, develop their potential ability and continuously improve comprehensive quality.

\section{Practice and implementation of Central Chinese folk art in art design teaching}

In recent years, Henan higher art design education has developed at a fast speed. Many colleges carry out a series of teaching reform and exploration for design specialty. The topic of humanistic and social science under Henan Province Office of Education - New Trend of Traditional Folk Art and Design Education Reform in Creative Culture Era presided over by the author, the research team has been surveying and exploring how to continuously improve education and teaching quality, inheriting traditional culture in Central China in the process of creating diversified, perfect and characteristic art design education mode, protect local art resources and boost national creativity under the background of Central Plains economic region construction in Central China, and activity applying them in teaching practice of each member.

\section{Fusion of elective courses and practical courses of the specialty}

At present, all kinds of design colleges and design discipline in comprehensive colleges in Henan Province set up Chinese Folk Art and Folk Art Appreciation. Course setting and teaching mostly adopt appreciation teaching mode. In fact, the students majoring in art design may fuse traditional folk kart courses with Art Investigation, Art Survey and Design Investigation and go out for investigation of folk customs. Teaching may be based in theory and supplemented by multimedia teaching so that students can more visually know these folk art works. Through understanding traditional folk art, students' art cell and art perceptivity may be cultivated. This will greatly enlighten and help future courses of art specialty.

\section{Combination of special lecture and professional studio practice}

At present, many design colleges have implement studio system. The tutor of studio serves as the subject. A series of work is conducted according to the tutor's research project. The nature of studio in this paper is as follows: local folk art serves as the object of study; masters are employed to teach and guide; the tutor leads young teachers and students for research and practice, and innovation and development are conducted on the basis of inheritance. Besides, the studio should share resources and exchange with various colleges in the province.

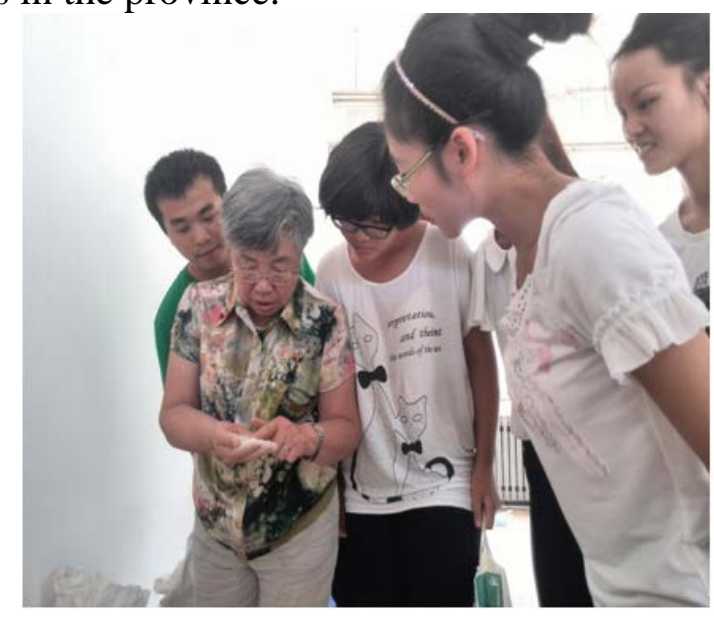

Fig. 1. Master Meng Yusong is explaining glaze materials of Ru Porcelain for students 
"Cuiqingtang Ceramics Studio" was set up by School of Arts in Henan Institute of Education where the author studies in 2013. It is a practical training studio set up jointly by Meng Yusong master of Chinese ceramic art and representative inheritor of national intangible cultural heritage. Meanwhile, it is also the first ceramics studio set up jointly by a university and a national master. The studio is dominated by design application study and practical operation and carries out beneficial exploration in style design and application technology. The studio invites multiple Chiense famous experts represented by the master Meng Yusong to give lectures and serve as the tutors of the studio. The tutors with profound ceramics culture knowledge and rich ceramics making experience directly guide students and carry out teaching practice for students majoring in design specialty. Students feel art charm of national intangible cultural heritage - Ru Porcelain with zero distance and can learn ceramics making techniques and skills. Meanwhile, Chinese and foreign art design philosophies are fused in traditional ceramics technique and a wide and effective platform is offered for development and innovation of traditional art. More importantly, all forms of teaching and research activities conducted by the studio can generate positive and far-reaching influence on inheritance and development of national intangible cultural heritage - Ru Porcelain.

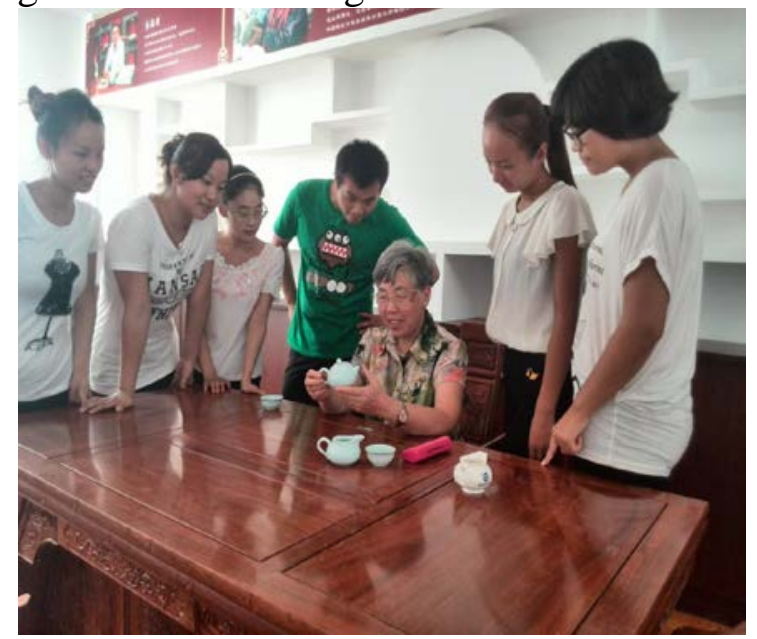

Fig. 2. Master Meng Yusong is explaining the style of Ru Porcelain for students
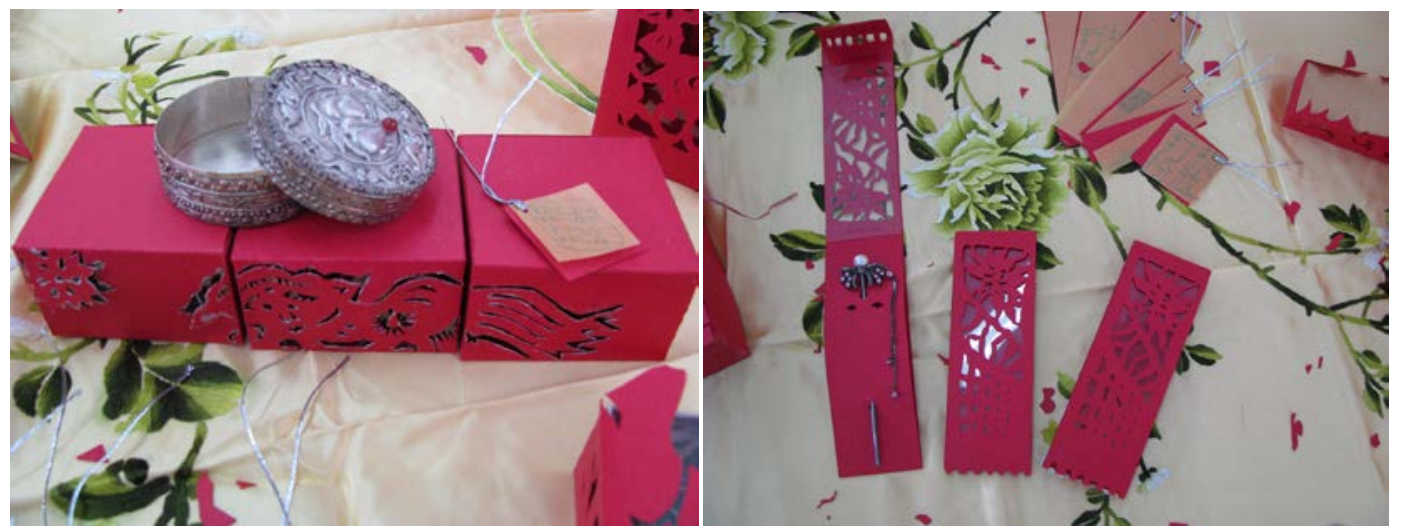

Fig. 3. Accessories Packaging designed with traditional paper cutting being the element students; works designed by: Zhang Xin

\section{The main research and design object of the traditional folk art in the Central Plains of China}

In the process of design teaching, folk art survey contents are studied through special design and other courses. Traditional culture elements are introduced in teaching content as the source of design idea. Teaching cases are introduced to stimulate students' learning interest and creativity. Teachers may teach traditional cultural theories to students and apply modern design methods to recreate folk art works and achieve design practice. The teaching process may be recorded for model teaching. 
In course design, firstly, it is required to confirm the method to introduce traditional culture elements in teaching as per teaching program. Then, teachers may guide students to apply field survey, document research, actual operation and experience to dig and analyze set traditional culture elements so as to find out creation elements and inspiration and create design thought, methods and performance for designers. Finally, mutual evaluation of achievements may be used to promote each other and improve.

Summary: "design innovation” and "people first” are development aim of folk art in the new century and also should be the development direction of folk art education. Folk art heritages in central China are very rich, so it is required to attach importance to protecting and inheriting folk art culture. The best method is education. Through education, folk art skills and culture can be taught to a new generation. They will interpret traditional culture according to their understanding of traditional folk art from new perspectives so as to blend in cultural innovation consciousness in new era. This is the fusion of traditional culture and modern culture and also the new reform trend of traditional folk art design education.

\section{Acknowledgments}

This paper is subsidized by the research project of humanistic and social science under Henan Province Office of Education - New Trend of Traditional Folk Art and Design Education Reform in Creative Culture Era

\section{References}

[1] Chen Meizhen, "Localization": a thought on art design education reform in the 21st century. Journal of Aesthetic Education, 2011 (2), p80-83.

[2] Gong Junsheng, On significance and value of folk fine arts teaching. Art Science and Technology, 2013 (5).

[3] Zhang Chunling, Exploration of building space design teaching based on Central Chinese folk art. Design, 2013 (8), p86-87. 